\title{
Markets and Economic Change
}

Moacir Palmeira

\begin{abstract}
Based on field work in the Zona da Mata of the State of Pernambuco, Brazil, this article discusses the transformations of the sugar estates and mills of the region through an analysis of the local "feiras" and markets in which workers who had been expelled from the estates were able to buy the items for their subsistence. Besides signaling the growth of a rural proletariat, the expansion of rural markets ("feiras") revealed the emergence of smallholders who had gained a degree of autonomy inside the sugar estates. The system for provisioning the regional rural population, which had previously been controlled through the sugar estate general stores ("barracões") was thus transformed. The counterpoint between feira and barracão reveals the complexities of change in the region and demonstrated the importance of ethnography of market places for the understanding of wider processes of social transformation.
\end{abstract}

Keywords: feira, markets, sugar estates, sugar mills, barracões, rural proletariat, smallholders, social transformation 


\title{
Markets and Economic Change $^{12}$
}

\author{
Moacir Palmeira
}

"I cannot understand how it is possible ... with poverty on the increase among the population, to have in Palmares a market lasting three days, where by two o'clock in the afternoon on Sunday there is nothing left to sell”. (S., former market trader, sugar estate manager and barracão assistant).

The process of expulsion of the "moradores" 3 of the sugarcane estates in the Zona da Mata area of Pernambuco State, which began in the mid -1940s and increased in pace in the following decades, represented more than merely the proletarianization of rural workers. It amounted to a new division of labor which affected both the actual process of production within each agricultural unit and the distribution and consumption of subsistence products. ${ }^{4}$

Although, from a technical point of view there was no agricultural revolution as such, the organization of labor on the sugar estates ${ }^{5}$ underwent

1 Originally written for an internal seminar at the National Museum in 1971, this article has never been published. For this edition, we have incorporated the photographic register taken by the author in Palmares, 1971. The research was part of the project "Employment and social transformation in the Northeast" coordinated by Moacir Palmeira. For an overview of the context, the theoretical discussions and the unfolding of the research explained by the author, see Leite 2013:435-457.

2 [Editor's Note] Four words compose the commercial landscape described in the text: barracão (general store inside the sugar estates and mills), feira (marketplace, fair), mercado (municipal market hall) and comercio estabelecido (established commerce controlled by the businessman of towns).The word feira designates an open-air market held at regular intervals, usually at the same place. It is not only a marketplace but also a particular market-time: a certain day in the week and the period that the market lasts. On the other hand, the sections of the feira are also called feiras but qualified by the product, i.e. feira da farinha (flour market). Then, feira could be a street-market, a market time and a market section.. We chose to keep the word in Portuguese to avoid misunderstandings. We have kept the word "market" for the title to underline the general discussion that the article proposes: through the ethnography of the "feiras", to discuss the place of the market in social transformation.

3 [E.N.] In rural Northeast of Brazil, the term morador -'dweller' or 'inhabitant'- referred to a peasant who lived in the sugar estate with their family in a morada (a house with a plot of land). The morada established obligations of the peasant towards their patron.

4 In this work, in the absence of any better phrase, I use the term "subsistence products" to designate those consumer goods (generally agricultural or semi-processed) defined socially in the area under consideration as essential to the maintenance of the labor force, and capable, under current conditions, of being produced locally.

5 The term "engenho", with the disappearance of the old "bangüê" (a watermill "engenho"), continued to be used 
considerable change. The practice of payment for daily work, which was widespread in the region until the end of the 1930s, was replaced by a more flexible system of payment by "tarefa" (task) and/or by "conta", ${ }^{6}$ which saved the production unit the heavy costs of supervision. The demands of the labor laws that had been imposed over the owners during the 196os encouraged them to rely on "empreiteros" (contractors) - a kind of "other's labor" entrepeneurs - as intermediaries between themselves and their workers,. Furthermore, the traditional practice of landowners - leasing plots of land to the "moradores"in return for labor and other services -, was eliminated over time.

In a parallel process, the presence of this "freed" labor force in the towns of the region was not only responsible for a large increase in the population of these towns, but also for a radical alteration in their social make-up. From being towns populated largely by public employees, they transformed into agglomerations of rural laborers available for work. The decrease in activity of the sugar-mills at certain times of the year and the more or less chronic financial crisis which afflicted agriculture in the state of Pernambuco encouraged part of this population to seek work, temporarily or permanently, outside the sugar cane production sector. A good part of this population, however, continued to work permanently on the estates, either legally or clandestinely (which did not stop them from seeking extra sources of income in the towns). The most important consequence, however, was that those workers now had to fend for their own means of subsistence, previously provided by the sugar mills and estates. ${ }^{7}$ Over time, a market was

in the region to denote the sugar cane plantations, both those belonging to suppliers and those owned by the sugar processing plants. [E.N. In the present translation, engenho will appear as "sugar estate" or "estate" and usina will be translated as "sugar mill". In the author words, "The term engenho referred in the past to the plantation-sugar mill complex and, more specifically to the sugar mill itself where the processing was carried out in order to produce sugar. Today the term is used in Pernambuco, where the last actual engenhos stopped grinding in the 1950's, to refer to any large property which plants sugarcane to supply a modern usina. The senhor de engenho, the property owner of an engenho, is also referred to as fornecedor de cana or sugarcane supplier. Usina is a sugar mill which besides receiving sugarcane from the senhores de engenho has also its own plantations. Usineiro is the owner of an usina." (Palmeira 1979:90)].

6 Both "tarefa" and "conta" are methods of payment by productivity. The former, which was in fairly general use in the 1940s and 1950s, referred to an area of land measuring 25 by 25 "braças" (braça $=2.2$ meters) measured out at the beginning of the week to be worked by the laborer, without further reference to time. At the end of the week, he would be paid by the number of "tarefas" completed, in accordance with the owner's assessment of the value of the "tarefa". The "conta", which was generally adopted after the coming into force of the Rural Labor Law, referred to an area of approximately 10 by 10 "braças" which, in theory, was equivalent to the minimum daily wage of a worker.

7 Through the system of "barracões" - general stores on the estates which had a monopoly of sales within their areas - or through the letting of areas for growing "subsistence" crops for the workers. [E.N. Through the text, we use the original word to designate the social configuration that these general stores have inside the sugar estates and mills]. 
formed for the products of those "moradores" who remained on the estates. If traditionally the "moradores" were obliged to hand over the produce of their plots or holdings to the "barracões" and purchase there what they did not cultivate themselves, the new "trabalhadores de rua" -street laborers- 8 were unable to make purchases in the "barracões". Once the "tied system" of submission had been abolished, the country dwellers acquired an alternative means of selling their products.

In areas where development of the sugar estates had been slower and where there was an available "stock of land", there was an incentive for small scale production, despite conditions which favored plantation expansion and the actual expansion of sugar plantations during the period. For some of the former plantation owners, the possibility of returning to sugar cane cultivation often depended on the splitting up and sale of part of their land. On the other hand, the sugar mills' need for working capital seems to have led them to avoid tying up their capital in land. At the same time, the owners of the sugar estates, having expelled their workers, found themselves with the problem of indemnifying those concerned, which was not infrequently resolved by the grant of land. Some cases saw the paradoxical situation of "moradores" who had never possessed their own plot of land, but who, once "dismissed form employment" found themselves in the position of independent agriculturalists on land leased from their former employer. ${ }^{10}$ In short, it seems that there was an opening up of the land market which favored small scale cultivation.

Even though it is difficult to evaluate, the activation of the circuit of exchange of subsistence products gave rise to an appreciable growth of "feiras" - open-air markets - in the Zona da Mata. It was this change which constituted perhaps the principal support for the changes noted. They "feiras" provided employment opportunities for workers expelled

8 [E.N.] During the research, the expression "trabalhadores de rua" (street laborers) referred to the peasants living in the small towns of the countryside, who were expelled from the sugar estates or who were waiting for a new house in other sugar estate. In other words, they were "moradores" who were compelled to leave their moradas and who are living in town.

9 Cf. Genestoux, 1967.

10 In the north of the Zona da Mata in Pernambuco there is currently a distinction between hereditary leasing (aforamento) and leasing (arrendamento) and between hereditary tenant (foreiro) and lessee (arrendatário): the tenant lives on the land which he cultivates, while the lessee necessarily lives elsewhere. It was Vera Maria Echenique and Luis Maria Gatti who drew my attention to this distinction which they noted in their travels in the region in February 1971. When I started to process the material I had gathered in the field, I noticed how strictly these two categories are employed by the rural smallholders and laborers in the region. 
from the sugar estates, and at the same time acted as a conduit for the redistribution of "wealth" among a particular section of the population, and as distribution centers for small scale rural production.

Obviously things were not so clear-cut as the above description might imply, and there were important variations depending on the particular characteristics of differing sub-areas and on the specific histories of each market which, it should be stressed, had nearly always existed prior to these developments. Above all the transformations were not so simple because the "feiras" co-existed with other forms of distribution, from the "barracões" to regular urban commercial outlets.

The changes in question did not materially alter the downward vertical direction of the flow of manufactured goods which was a feature of the "barracões" of estates and mills: the "feiras" of the Zona da Mata perhaps continued to be (in terms of the value of the produce) essentially suppliers of manufactured goods to the rural population. The subsistence products sent to the markets by small producers did not reach consumers in the major urban centers of the region, or, if they did, had only a marginal effect on them. What was new was the commencement or increase in the flow of agricultural subsistence products among the rural population, previously overlooked within the general flow of goods which, through the "barracão" system, reached consumers living on the sugar estates. At some point, there was a break in the system which made the sugar estates veer between periods substantially dedicated to the cultivation of cane and the development to a greater or lesser extent of "subsistence" agriculture. The products of this subsistence economy started to compete for land with sugar cane at a time of major expansion of sugar cane cultivation.

Table 1: Cultivated Areas (in Hectares) for Sugar Cane And Cassava in the Zona Da Mata Area of Pernambuco State, 1950-1960

\begin{tabular}{ccc} 
& $\mathbf{1 9 5 0}$ & $\mathbf{1 9 6 0}$ \\
\cline { 2 - 3 } Sugar Cane & 160,683 & 247,417 \\
Cassava & 15,784 & 31,135 \\
\hline
\end{tabular}

Sources: Pernambuco Economic Census 1950 (IBGE 1955); Pernambuco Agricultural Census 1960 (IBGE 1969)

But whilst there was an increase in the area producing cassava, the staple diet of the poorer section of the population in the region, there was an increase in complaints that "nowadays people have to buy cassava flour in the market". 
Clearly the processes whereby agricultural subsistence products are exchanged do not function in isolation from the processes involving manufactured goods. Whether through the establishment of fixed prices for certain products, or through competition with similar products produced in other areas which arrive in the region through established commercial outlets, or simply through the role played by the latter in the whole process, these processes are ultimately linked to the national market. They do, however, retain a relative autonomy in their functioning, both as regards the procedures for sale and purchase and for the setting of prices, in terms of the composition of the intermediate parties involved.

It is also important to remember that the effective total of transactions involved is small, albeit that the lack of precise figures and the legally undefined character of the economic agents have led to the irrelevance of the value of the transactions being exaggerated. However, to ignore the social relationships involved is tantamount to overlooking a social mechanism which seems to have played a decisive role in the changes which occurred.

\section{The "Feiras" and the Towns}

The remarks below refer basically to two "feiras" in the Zona da Mata area of Pernambuco: Palmares and Carpina.

The town of Palmares (a self-governing municipality since 1873) is older than Carpina and has always been considered an important "commercial center". It owes its development, according to local historians, to its position at the end of the Great Western railroad, in the second half of the last century. But, "as more stations were opened, the traffic at Palmares started to fall off". However, "the company's head office continued to be located here, with all its consequent traffic, together with the workshops, where locomotives were reassembled, wagons fitted out and an internal repair service maintained. And there was an additional factor of some importance: the railroad tracks from Palmares to Recife were narrow gauge, whilst those of the so-called extension were broad gauge. This meant an obligatory transfer of cargo in Palmares (...)". ${ }^{11}$

The development of Carpina (a municipality since 1928) seems also to have been linked to the growth in the number of railroad lines, being at the

11 Cia. Telefônica de Palmares, 1965. 
junction of two important branches. For this and other reasons, the town was also considered, like Palmares, to be a "commercial center".

Despite these similarities, to which one can add the fact that the two towns were of more or less equal size and the fact that economic activity in both centered on the cultivation of sugar cane,${ }^{12}$ the social order that prevailed in each of them seems to have been markedly different. Palmares was considered an "exclusively sugar cane" area, in which the concentration of such estates was much higher than in Carpina.

Table li: The Classification of Agricultural Properties by Area (Hectares) in the Municipality of Carpina - 1960

\begin{tabular}{l|c|r|r|r}
\multicolumn{1}{c|}{ Band } & \multicolumn{2}{|c|}{ Properties } & \multicolumn{2}{c}{ Area } \\
\hline \multirow{2}{*}{$0-3$} & Number & $\%$ & Total & $\%$ \\
$3-10$ & 244 & 35.31 & 535 & 2.72 \\
$10-30$ & 286 & 41.39 & 1,827 & 9.29 \\
$30-100$ & 87 & 12.59 & 1,641 & 8.35 \\
$100-300$ & 42 & 6.08 & 2,289 & 11.64 \\
$300-1000$ & 18 & 2.60 & 3,531 & 17.96 \\
$1000-3000$ & 14 & 2.03 & 9,840 & 50.04 \\
Over 3000 & - & - & - & - \\
Total & - & - & - & - \\
& 691 & 100.00 & 19,663 & 100.00
\end{tabular}

Table lii: The Classification of Agricultural Properties by Area (Hectares) in the Municipality of Palmares - 1960

\begin{tabular}{l|c|c|c|c}
\multicolumn{1}{c|}{ Band } & \multicolumn{2}{c|}{ Properties } & \multicolumn{2}{c}{ Area } \\
\hline \multirow{2}{*}{$0-3$} & Number & $\%$ & Total & $\%$ \\
$3-10$ & 2 & 1.32 & 3 & 0.07 \\
$10-30$ & 4 & 2.65 & 40 & 0.10 \\
$30-100$ & 39 & 25.83 & 796 & 1.96 \\
$100-300$ & 33 & 21.81 & 1,787 & 4.41 \\
$300-1000$ & 31 & 20.53 & 6,508 & 16.10 \\
$1000-3000$ & 42 & 27.82 & 31,267 & 77.36 \\
Over 3000 & - & - & - & - \\
Total & - & - & - & - \\
& 151 & 100.00 & 40,401 & 100.00
\end{tabular}

Source: Rosa e Silvo Neto, J.M. - Subsídios para o Estudo do Problema Agrário em Pernambuco, Recife, Codepe, 1963

12 Carpina has no sugar processing plant located within the municipality. 
Whilst in Palmares certain traditional forms of landholding in the sugar plantations had disappeared by the early years of the XX century, the estates in Carpina milled sugar until relatively recent times, "lavradores" (peasant farmers) $)^{13}$ are figures from the recent past. Tenant farmers still form a significant group there. ${ }^{14}$

Even though, once we get away from narrow municipal divisions such differences can become quite small, they seem to have some relevance when we consider the two "feiras". The shorter distance between the food producing areas and the marketplaces meant that the presence of direct producers in Carpina market was greater than in Palmares, that transport using draught animals was very important, and, perhaps, as the problem of storage was not so great as in Palmares, the established commerce was of less importance in supplying the "feira".

On the other hand, and here there is a lack of material on which to base conjectures, Carpina, where the "feira" is on Sundays, is a town on a circuit of marketplaces. The operators who sell manufactured goods and are known as ambulantes (itinerant traders), are market professionals ("professionais de feira") who have following schedule during the week: Monday - João Alfredo; Tuesday - Itabaiana (Paraiba State); Wednesday Nazaré or Limoeiro; Thursday and Friday - no market; Saturday - Goiana or Paulista; Sunday - Carpina. Palmares, where the "feiras" runs for nearly three days, does not seem to be linked to any circuit. The sellers of manufactured items are generally residents of the town and do not operate at markets in other locations. The most that happens is that "feirantes" (market trader)-producers operate in two stages: on one day of the week they go to the market at the nearest locality and on Sundays they go to Palmares with the remainder of their produce and any products purchased at these small "feiras", or, apparently more usually, they take their produce to Palmares on Sundays and sell the remainder at the market nearest to their home.

13 [E.N] The word "lavradores", in the original, has a particular meaning in the region] The "morador" who grew sugar cane in partnerships.

14 [E.N] The word in the original for tenant farmer is foreiro, which is also a specific social relation inside the sugar estate. The foreiro is also a morador - he has a house and a plot in the sugar estate - but he has greater autonomy due to the payment of an annual rent to the estate owner. 
The relative self-sufficiency of the subsistence product circuit seems to be reflected in the actual division of the "feira". The "feiras" studied appear to be divided into well-defined sectors (manufactured goods; handicrafts; meat and fish; flour and cereals, vegetables, greens and root vegetables; fruits; crockery), even though certain combinations of products tend to form their own category. ${ }^{15}$

It seems to us symptomatic that rural workers and "feirantes" (market traders), when interviewed both at the marketplace and away from it, rarely referred to the "feira" as a whole, but only to "the flour feira", "the fruit feira" (which at a time when the most common product was the banana, was known as "the banana feira"), "the meat stands", "the fish stands", "the market", "the market stalls". Whilst we do not have the factual basis upon which to make a systematic examination of this classification (which is incomplete, because it consists only of expressions found in the data collected), we should like to draw attention to the fact that the sections selling regulated products - (meat, charque (jerked beef), sugar), are not classified as "feira", this term being reserved for those sections where there is some variation in prices and, perhaps, a greater turnaround of sellers. Similarly, there is a clear distinction between bancos de feira - market stands (which are large covered stalls or canvas spread on the ground), and barracas (stalls -a term reserved for the stalls surrounding the Municipal Market Hall), which are permanent and controlled by wealthy traders. The latter distinction can be illustrated by the answer given by one interviewee who was talking about the sale of cabbages in response to a question from the researcher as to the lack of variation in prices between the stalls (barracas):

Q. Why is there only one price for everything? Why aren't the prices different on other stalls?

A. Because ... let's put it this way, these markets are ready markets. So the people who go to buy are the same people who want to sell from those little stalls, so they also buy in that Municipal Market. So you can

15 [E.N] Although cassava flour was the main product, in the "flour feira" and the Municipal Market Hall the flour section includes cassava, wheat and corn. 
see that nowadays everybody does business so that there's no space for anyone else to come in. ${ }^{16}$

It seems that there is a concern on the part of producers not to take more than one product to the "feira":

"I only sell one kind of merchandise at a time. We make a calculation of what's best and take it" ${ }^{17}$

"Feirar" (to sell in the feira) and "fazer feira" (to buy in the feira) are defined socially as male activities. Or, as a Carpina smallholder said ${ }^{18}$ :

"Women don't sell at the "feira". Only when it's time of festivities and they go and sell to make a little money to buy a dress, or clothes for the children... Yet the wife of a smallholder knows the "feira". But there are women there who don't even know Carpina. The wife of a paid laborer never goes to the "feira". She is ashamed of not having a new dress to wear when she goes to the "feira". She only has her old clothes. With self-employed workers, the family goes to mass and then to the "feira". There's more freedom (...). A woman without a husband or children gets her neighbor to sell for her. She is too shy to go to the "feira" alone (...) because she normally has to go by horse, and she is ashamed of arriving in the town riding a horse".

A woman in the "feira", whether selling or buying, has to be "a widow, a spinster or with no husband". But, for whatever reason, doing the "feira" is viewed as a real chore (sacrifice), as implied in the complaints of a "morador" of Palmares:

"I buy things in the "feira", yes, every Sunday I have to suffer coming here to the Palmares "feira" (...). I don't send my husband to buy because he's already crazy. If he came, he would die (referring to the prices), if he came here, I know he would never get back home". ${ }^{19}$

But this is not a rule that applies universally to all sections of the "feira". In the manufactured goods section and among the stalls (barracas) generally,

16 A., the manager of a consumer cooperative of rural workers.

17 Carpina tenant farmer, growing cassava, maize, pineapples, potatoes and beans. Interviewed at home.

18 L., owner of thectare of land in Carpina. Interviewed at home in the presence of other family members.

19 T.D., a resident on a sugar estate. Interview recorded. 
there seems to be an important female element. And in the sections selling subsistence products, there is room for female vendors:

"it's the same here - said the smallholder mentioned previously and his son in unison - it's the same here, women only sell odds and ends, herbs, earthenware - and straw. Some sell green vegetables".

His daughter continued:

"Women don't sell flour in the "feira" because it's a very responsible job. It has to be handled by a man. Women only sell fancy little things. Flour or meat needs strength, which a woman doesn't have. A woman can't sell flour, because flour needs a lot of working out. It's not easy to sell flour."

The head of the family extended the scope of that exclusion to children, saying that it is only men who do the selling in the "feira", "women and children just walk around", but then qualified his remarks:

"There are people who buy in bulk and are homeless, they are the smartest, sometimes they set up more than one stall. The owner stays in one place and puts his son in the other".

Direct observation suggests that the exclusion is effective. Not a single woman could be noted selling flour at the Palmares "feira" in November and December 1969 (the period during which sugar cane was harvested and milled) or in May and June 1970 (the period between harvests). The few women in the flour "feira" worked in the area next to the meat stands, assisting their husbands, generally at the same stand. The register that we compiled in February 1971 (partial in the case of flour and cereals), however, found that there were 7 women - and 33 men - selling in that section, all 7 of the women lived in the town. In Carpina, a few women were noted selling flour in these three periods, but always within the Municipal Market.

By contrast, in 1969, there were only women selling in the pottery section at the two "feiras", and it was the same with spices and herbs. In 1970 and 1971, men were also noted selling pottery. This can be shown in tabular form as follows: 
TABLE IV

\begin{tabular}{lllllll} 
& \multicolumn{9}{c}{ Carpina } & \multicolumn{3}{c}{ Palmares } \\
& 1969 & 1970 & 1971 & 1969 & 1970 & 1971 \\
\hline Manufactured goods & $M>W$ & $M>W$ & $M>W$ & $M>W$ & $M>W$ & $M>W$ \\
\hline Flour and cereals & $M>W$ & $M>W$ & $M>W$ & $M$ & $M>W$ & $M>W$ \\
\hline Meat and fish & $M$ & $M$ & $M$ & $M>W$ & $M>W$ & $M>W$ \\
\hline Handicrafts & $W>M$ & $W>M$ & $M>W$ & $W>M$ & $W>M$ & $W>M$ \\
\hline Vegetables and greens & $M=W$ & $M=W$ & $M=W$ & $M=W$ & $M=W$ & $M=W$ \\
\hline Root vegetables & $M$ & $M$ & $M$ & $M$ & $M$ & $M$ \\
\hline Fruits & $M>W$ & $M>W$ & $M>W$ & $M>W$ & $M>W$ & $M>W$ \\
\hline Pottery & $W$ & $W>M$ & $M>W$ & $W$ & $W>M$ & $M$
\end{tabular}

M - Men; W - Women; w - women within the Municipal Market Hall (or in insignificant numbers)

$\mathrm{M}>\mathrm{W}$ - more men than women; $\mathrm{W}>\mathrm{M}$ - more women than men; $\mathrm{M}=\mathrm{W}$ - same number of men and women

\section{Sellers and Buyers}

The variations from one sector to the other with regard to market traders are so great, that generalizations become difficult. It is certainly true that there seems to be a certain homogeneity with regard to the end consumers, the large majority of whom are rural laborers in the case of Palmares, rural laborers or smallholders in the case of Carpina. However, it would be a simplification to fail to note the visible presence, well publicized by the vendors, of urban consumers in the manufactured goods, fruit and vegetables sections. In contrast to the practice in the "flour feira", for example, there are women buyers (usually household employees). In the case of Carpina, it seems that the presence of consumers from Recife is of some importance (many of them own "granjas" ${ }^{20}$ outside the city), especially for the fresh meat counters in the Municipal Market and in the fruit and

20 [E.N] In Carpina, the word granja (farm) is used to designate small and medium size rural properties farmed by wage workers and owned by middle and upper class people from the cities (generally from Recife). Most of the farms are focused on raising poultry. At the time of the research, some of them were beginning to plant sugar cane, becoming sugarcane suppliers. 
vegetables sections. For other products, however, it appears that these consumers prefer the city supermarkets. ${ }^{21}$

With regard to the vendors, although the presence of middlemen is the normal rule, the differences between these middlemen are too great for them to be considered as a whole. The register of the Palmares "feira" reveals not only that direct producers or middlemen appear, as one might expect, much more frequently in the sections selling food, but, not so obviously, that practically all the sellers of manufactured goods are professionals who have always been market traders or people who, having formerly worked on the land, have worked in "urban" trades before becoming market salesmen. In contrast, the great majority of those selling flour or cereals are either farm workers or rural laborers who have left the country and gone directly into business.

If that appears to be a fundamental division, there are also big differences in the sections which trade in subsistence products. The differences seem to be connected with the conditions under which each type of product is produced, the greater or lesser perishable nature of the product, and the availability of capital to the producers and middlemen.

In the "flour feira", for example, where flours and cereals are sold, and where most consumers are rural laborers, there are many different situations. There are many smallholders who produce their own flour, many of them own flour mills ${ }^{22}$; in Carpina they come from the municipality itself, in Palmares they come from the surroundings ("agrestes") ${ }^{23}$, from Agreste, or from the north of the State of Alagoas. They rarely sell only their own produce; as a rule the flour is theirs, but the maize, rice and certain kinds of beans are purchased, either directly from the wholesalers or at the municipal market. At times when there is no flour in the region for one reason or

21 "My clientele is very special. They are middle and upper class people: farmers, public employees from the National Malaria Service and from the Federal Railroad Network and landowners". People from neighboring towns also shop at the supermarket "because there are no shops of this kind in the whole of the north Mata". "Incredible though it may seem, even people from Recife come to shop here". (S., supermarket owner).

22 Setting up a hand operated flour mill seems to be relatively simple and there are many owners of hand operated mills. There are estates where you can find 10 or more flour mills owned by local people. In the areas farmed by tenants or smallholders, they are even more numerous. Nevertheless, not all those who grow cassava have their own flour mill. Most cultivators of cassava use a neighbor's mill to grind their own cassava, paying the owner a half bowl for each ten bowls produced or a half bowl for each pressing.

23 When rural workers in Palmares refer to the "agrestes", they mean the surrounding region which supplies Palmares, the border area between Zona da Mata and Agreste. Similarly, when they talk of the "matutos", it is the people living in the outback ("agrestes") that they mean. 
another, they operate simply as middlemen. But, in general, the flour comes from the "matutos"(peasants). Selling directly in the "feiras" is not seen as an easy option. There are problems with the expenses of transport and storage:

"I don't sell at the "feira" because it's very expensive to take my produce there. I have to pay two thousand cruzeiros per sack for transport and I still have to pay for the pitch at the "feira". If I don't sell everything, I have to take it back home. I don't make any profit." ${ }^{24}$

There are those who buy flour from the peasants and sometimes from "the trade" (a category which includes both the wholesaler and the Municipal Market Hall). These are the small middlemen or retail dealers. In Carpina, these small middlemen spend Saturday nights at the entrance to the town, "by the cemetery gates", awaiting the smallholders:

"When you go out at night, you see everybody discussing prices. 'T'll pay so much', says one, and the other says, 'I'll pay so much'. Some people (producers) don't even get off their horse. They sell their produce there and then and go away."

These middlemen, according to the same interviewee, are small operators. Sometimes they borrow money, and pay a high rate of interest so that they can buy a load.

"When the buyer is a small dealer, he is allowed to pay later. When he returns he cries and begs a reduction in the price because business was bad at the feira". ${ }^{25}$

These small middlemen who deal in flour generally have "a little room" where they store their stock and it is difficult for them to sell in more than one market.

Finally, there are a large number of sellers who depend on wholesalers or shopkeepers in the municpal market. They have virtually no capital, no storage facilities, and are little more than employees of the dealers. They generally buy in consignment and only operate with produce purchased from a single shopkeeper who obliges them to set up their "stalls" in front of the shop.

24 Owner of 2 hectares in Carpina, dependent on the owner of a hand-operated flour mill, in return for which he supplies not only a part of his produce but also his labor when required.

25 L., owner of 1 hectare in Carpina. 
In the green vegetables sector ${ }^{26}$, the position is very different. There is no interference from established commerce. It is a relatively "open" sector. According to a green vegetable seller in Carpina, "green vegetables are the cheapest kind of produce, you don't need capital". This means a larger presence of direct producers, though it seems, however, that this is counterbalanced by greater opportunities open to poor middlemen - also that the rule is to sell the product as quickly as possible. As a producer of green vegetables in Palmares says ${ }^{27}$ :

We put it on the ground to sell it, it stays there until the afternoon. Kale is not something that can stay out all the time in the sun. If it was fruit, cucumbers, maxixe, okra, they can tolerate sun, but kale we pick in the afternoon, douse it in water, tie it in bunches, put it back in water, it spends the night in water, and early in the morning we put it in baskets or in bags and bring it to sell. Our motto is to sell quickly, because if it wilts it loses its value. If it's wilted, it's lost its value. This lady here (indicating a green vegetable seller) buys and puts those bunches of kale in the street. She buys cheaper (...). She'll sell them there for 200, or maybe she won't sell, but the loss is hers to bear, isn't it? Now if it was fruit, bananas or oranges, no. I'd put my little load there in a corner, or my basket, and say: '2o cruzeiros here, 20 cruzeiros'. They don't wilt in the sun, they're good in the afternoon. But, you know, green vegetables are a different thing altogether, aren't they?.”

"Moradores" of the sugar estates, who want to supplement their wages with a little extra earnings from selling the produce of the "matutos" (peasants) are also attracted to this sector as middlemen.

\section{Prices and Customers}

The methods for establishing the prices of goods also seem to vary between the different sections. There are sections where prices are regulated by law and there are also sections, such as manufactured goods, where there is a fixed lower limit beyond which prices cannot go. In these sections the price is the same from the start to the end of the "feira".

26 The category "green vegetables" is quite wide. A middleman who sells only green vegetables lists his stock as follows: "parsley, onions, green peppers, okra, lettuce and tomatoes".

27 J.A., a resident on a sugar estate. Interview recorded. 
In contrast, where fruit and, above all, vegetables and greens are concerned, the difference in prices, both between different stalls and on the same stall during the course of the "feira", seems to have no limits:

"I lower the price and I sell everything. I have never had to go home with some produce", ${ }^{28}$ says one small producer. "Now the price here is bad because there are many pineapples coming from Paraiba (...)".

He goes to Carpina on Saturday nights 'to get the prices'. He tries to sell as much as possible in the early hours of the morning, because from 9.00 o'clock onwards the trucks arrive from Paraiba and the price falls. When there are a lot of pineapples, he charges " 200 for a large one and 100 for a small one". When they're scarce, he charges " 300 for a large one and 200 for a small one."

The same is true for the small middleman, who has tied up a little capital, it is preferable to sell at any price and recover some of what he has disbursed, rather than keep products without anywhere to store them.

The flour "feira" is a special case. The middlemen, who only deal with goods on a sale or return basis, have extremely limited room for manoeuver when fixing prices:

"We buy a sack of 70 kilos and afterwards we calculate how much can we ask for a liter". ${ }^{29}$

The middlemen, who buy from the peasants, make the same calculation with regard to their product:

"The peasants bring along their goods and start selling to anyone they meet (...)"

They pay a thousand cruzeiros to the town hall for the market pitch and another 500 per sack, which they may or may not sell. They then fix the price in line with what they have paid for the product. But when the "feira" is very weak, they end up selling for the price they paid. ${ }^{30}$ Even though the peasants can sell to a retailer more cheaply than commercial outlets, the fixing of sale prices seems basically to depend on the wholesalers:

28 Carpina tenant, already quoted.

29 Information supplied by a member of a group of traders from Agreste, selling flour purchased in the shops.

30 Small middleman, selling flour bought from the "matutos". 
"Wholesalers sell in the "feira". When they have plenty of flour, they place it on a number of stands. When they have little, they close ranks to guarantee the price." ${ }^{31}$

There is almost no haggling in the flour "feira". Competition between sellers seems to revolve basically around the quality of the product, which is handled by nearly all potential buyers and in some cases tasted. Sometimes the customers complain about the price, but they never ask for a discount. The only attempt at haggling that we witnessed was by a "rich" woman in Palmares, who, in attempting to make excuses to us for buying at 11.00 o'clock on a Sunday morning, tried to persuade a group of producer-traders from Agreste to sell to her at a lower price. She was treated sarcastically by the traders and abruptly withdrew from her purchase. The comments which followed were even more aggressive and ironical. One of the traders said:

"Poor people are much better buyers. It seems that in the case of the rich, we must sell at a lower price than we paid”.

We did, however, meet an old man who had been a market trader in Caruarú and had been selling for a year in Palmares, who complained bitterly about price disputes:

“Look: isn't it strange that in a place of this size we don't have any customers. But it's true. Why? When I arrive, I mark my flour at 1,40o. My friend here (indicating the neighboring trader), who has maybe bought more cheaply, marks his at 1,300 . OK. The other one in front, who paid the same price or perhaps a bit more than I did, marks his flour at a sale price of 1,200. So everybody else has to lower their price so they can sell. What's bad is this lack of cordiality between the traders. How can we get customers like this?" ${ }^{32}$

It seems that the old man was using the term customer ('freguês') as a synonym for buyer (he subsequently complained that up until that time he had not sold a single bowl of flour), whilst in Palmares the term 'freguês' seems to denote a very specific relationship: 
"What they call a customer (freguês) here is a person who buys on eight days credit, he buys on a Sunday and pays the next Sunday. It works as follows: you have a stall where you sell flour ... Someone comes and buys two or three times in cash. The fourth time he buys, he starts a conversation with the seller. As he is leaving, the seller says: 'Take more'. The person says: 'Look, man, I can't take more because I don't have the money'. The trader says: 'Do the whole "feira" and pay me next Sunday'. So he becomes a customer (freguês). The following Sunday, he pays his account from the previous market and makes a new purchase, which he will pay for in eight days' time." ${ }_{33}$

According to another respondent, this is the so-called "eight day customer" (freguês de oito dias"), who is to be found in retail sales. But there is also, or at least there was at the time this respondent traded in the "feira", the "market customer" or "ribirista", "a middleman to whom the peasant always sells his produce". ${ }^{34}$

Whatever may be the case, to judge by what the traders say and by what we were able to perceive from direct observation, this type of customer relationship does not seem to be particularly widespread in the case of retail sales. According to an old market inspector, buying in the "feira"

“is completely free. People buy from whom they wish. If it's very expensive, leave it for later ... (...) There was never this business of regular customers. It's not possible. People sell to anyone. It's like that. (...) Surfeit is what makes the price go down."

Some traders say they have regular customers (freguêses), but they add:

"but there's only one price".

There also do not seem to be any special privileges attached to the quantity of goods purchased. The buyer always receives a small extra portion of flour, irrespective of whether or not he is a "customer". On the other hand, we only noted instances of there being 'eight day customers' when the

33 T., former inhabitant, and employee of the Federal Railroad Network . Comments made when we were interviewing a market trader in the "favela" (shanty town), who was answering our questions regarding customers in an apparently vague manner - "sometimes yes, sometimes no".

34 S., an official of the rural workers union, who had formerly been a manager, a shed owner's assistant and a market trader. 
transaction was between market traders (and the traders themselves seem to constitute an important group of consumers) or between rural laborers and the owners of market stalls.

In sectors such as fruits, green vegetables and root vegetables, while there may be customer relationships between producers and middlemen, they do not exist in retail sales and the actual concept of "eight day customer" seems to have no relevance. Phrases such as

"I do have regular clients but they are not very defined" or "I have regular customers (freguês) when there are not many sellers, when there are a lot I don't have them"

suggest that here the term customer (freguês) is simply a synonym for consumer. The reply given by a producer-trader seems to be more explicit:

“I don't have regular customers. I sell to anyone (...). I don't sell on credit. Here no-one sells on credit... We sell to friends on credit, but only when they are well known to us". ${ }^{35}$

This variation between sectors as regards the fixing of prices, from sectors where the laws of supply and demand operate freely or where "a surfeit is what makes the price go down" to sectors where the prices are regulated on a national basis, from sectors where the "eight day customer" can be found to sectors where no such thing exists, must be relativized. Firstly because we do not have a complete picture of the bargaining power of the different groups of producers in their relations with the middlemen, or of the logic which governs their economic decisions. Secondly, and more importantly for the purposes of the present work, because the "feira" is not a level playing field. The various sections of the market differ not only because of the various products sold or because of any other substantive features. They form a hierarchy. ${ }^{36}$ And this hierarchy, which seems to reflect the actual socially determined "pattern of consumption" of rural laborers

35 Carpina tenant, already quoted.

36 The importance of flour in the local diet is reflected in throwaway remarks by the interviewees, such as: "... the proper feira, the one of cereals...”, “... flour which is what we eat...”, or “... on Sundays I go out. I wake up in the morning, grab the bag and go out. At home we go through zbowls of flour per week. Only for eating the flour...” (T.D., resident on a sugar estate. Interview recorded). 
and smallholders, ${ }^{37}$ is present in the decisions that are made in each sector:

"Today I brought in 61 bunches of kale. I got there and I told her [a retailer of green vegetables]: 'Did you know that the price of my produce has gone up?' She said: 'Why? Because it rained?' I said: 'No. Because everything's very expensive. So my goods are also now more expensive (...)". ${ }^{88}$

\section{Commerce, Feira, Municipal Market, “Barracão"}

If the key sector of the market is flour and cereals, as has been suggested, and if, as is probable, the control of this sector is in the hands of the wholesalers and the traders of the Municipal Market, everything leads us to believe that the "price of the feira" (preço de feira) and the "stores' price"(preço do comércio) are one and the same thing. This, however, is problematic, because it pre-supposes an identity, at least of interests, between established commerce and the owners of stalls of the Municipal Market. Now, even though there is a lack of data to support definitive claims, these two groups not only appear to have very different social origins - "established commerce" always forms part of the local elites, its members are generally the offspring of businessmen, and their businesses often have branches in a number of different towns, while the owners of market stalls are from a humble background, very often ex-peddlers who have established themselves but who never operate in more than one marketplace. Their commercial interests and their attitudes to the market appear to be different. While the established commerce maintains that it is going through a crisis, as evidenced by the number of bankruptcies that have occurred in recent years and by the increasing presence of businesses from Recife operating in the interior, as in the case of Palmares, or by stagnating sales, as in the case of Carpina, market traders seem to be, if not in the process of a rapid expansion, at least in a financial position to operate a number of stalls and to muster dozens of vendors for the Sunday "feira". While stall owners seek to operate by manipulating the prices at the "feira", established shop owners complain that the "feira" is a problem because

Cf. the publications by the Joaquim Nabuco Institute in Recife: Maciel 1964 and Gonçalves 1966.

L., trader in Palmares. 
"a market trader from the "feira" comes into the shop, buys goods without requiring an invoice and later sells the goods in the street without paying any tax, thereby acting in competition with established commerce" or "the biggest problem for business is the Sunday market". ${ }^{39}$

Whatever the nature of the relationship between established commerce and market traders, however, the Municipal Market seems to operate as a "cereals exchange" and the prices established there appear to be valid far beyond "the hall" and "the Sunday feira", reaching areas previously unaffected by business practices, such as the actual production process at the manioc mills..$^{40}$ Even the "barracão" (general store) has been affected.

Traditionally, the "barracão" belonged to the estate owner who, even where he employed a front man, would make all the decisions with regard to prices and the purchase of goods. At sugar mills, in addition to the general stores of the estates (barração de engenho) there was the general store of the mill (barracão de usina) which, as well as supplying the workers in the industrial sector of the mill, was also the exclusive supplier to the stores of each estate. There were mills which set up supply companies, which grew to be powerful, with branches in several places, and which had a complete monopoly over the distribution of subsistence products within their agricultural production units, either directly or through a tight system of inspection. At the beginning of the 1940s, a sugar plant in the south of Pernambuco announced that it had achieved the "abolition of "barracões" in private hands ..., where the workers were subject to every kind of exploitation". ${ }^{41}$

"The company goes even further. It maintains on each agricultural estate a store for the sale of basic goods to the inhabitants and workers, housed

39 Statement by a trader at a meeting we attended of the Carpina Trade Association. There was a conflict among tradespeople in the town with regard to market day. The major traders thought that the day should be changed to Saturday. The older tradespeople and small traders (retailers) preferred the "feira" to be on a Sunday. The split between them was so pronounced that the local Trade Association, in order to take a position with regard to the problem, carried out a kind of opinion poll among all the traders of the town. The small traders' view prevailed.

40 Payment in money to the owner of the flour mill is becoming more frequent with the introduction of the motorized flour mill, operated by the owner himself. However, irrespective of the type of flour mill, the relationship between the cassava producer and the mill owner as middleman seems to be dependent on "the market". Thus, a smallholder whom we interviewed (see note 16) told us that he sold his produce to the mill owner for less than the market price: "Because he's got to make a bit of a profit, hasn't he? For example, when the price of flour in the shops is 30 , I sell to him for 25 . This flour that I'm making here is already his".

41 Usina Catende S.A. 1941:36. 
in its own building, which is leased rent-free to a concessionaire, along with all the fixtures and fittings - shelves, scales, sales counter - without any rent or commission being charged. The only obligation imposed on these concessionaires is that of selling their goods at previously fixed prices, so as to avoid the exploitation of the country folk. The mill follows a strict policy of checking prices, quality and weights. The company also supplies free transport on its trains for the goods, so that they can be delivered to the most outlying properties, at prices corresponding to those applied in town. These sales outlets replaced the old "barraões" which were, up until then and in most cases, exploited by the owner or lessee of the estate or which were assigned to other operators in exchange for the payment of rent or a share in profits. In contrast to these "barracões", which represented a source of income for the owner or lessee of the estates, the sales outlets which exist on the estates of Usina Catende S.A. are an expense and a charge to the company, which seeks to protect the workers and inhabitants and ensure that they have better and cheaper food". ${ }^{42}$

It mattered little whether it was called a "barracão" or a "store" (venda), whether it belonged to the state owner or to a "modernizing" company, the institution ensured that the inhabitants were kept isolated from the mainstream economy.

Today, however, the situation is totally different:

"Today there are no fixed prices like in those days. The fixed price list came from the mill. There were inspections twice a week, they went to the "barracões" to see if they were selling. So the worker provided information to the inspector. Not today. They decided the prices, there aren't any fixed prices nowadays. That one over there, he buys flour, let's say, in the shops, he buys in bulk, he buys at a basic price of 3 thousand cruzeiros, let's say. Then he sells it in the "barracão" for 6 thousand, 6 thousand 500, 5,500, and so it goes on. The worker, poor thing, can't go to the shops, either he's stuck with paying the mark up, or he misses three days' work. The worker is over (...)".43

42 Idem, pp. 109-110.

43 A., resident of a sugar estate in the Palmares region. Interview recorded. 
With the end of "morador" and the generalization of contract work, the "barracão" has taken on a new guise. ${ }^{44}$ It is less and less a business run by the owner of the estate or the mill. Increasingly, the norm is a "barracão" leased to a third party. The operator is no longer "the capable lad trusted by the boss" of earlier times, but increasingly a businessman, often running a number of "barracões" and belongings of one or more owners, frequently living in town where he may or may not have other businesses. He no longer buys at places chosen by the boss, but at places where the prices are lower:

"In the "barracões" they sell everything. They sell flour, beans, sugar, kerosene, matches, salt, rice, cornflour, milk, sardines, potatoes, salted cod, charque (jerked beef), poor quality fish that you see in the "feira" which I think not even the tatu (armadillo) wants. Because they buy the stuff cheaply and sell at a higher price, so as to make a profit. And there are "barracões" which sell everything. The only things they don't sell are clothes and shoes, this kind of thing. But there are some which even sell these. But they are expensive (...)". ${ }^{45}$

And the prices in the "barracões", even if they are not shop prices, are related to them:

"Here's a case in point: the price of flour in the shops now, the cheapest is 5 thousand, isn't it? On Sunday it was 4 thousand, but the price now is 5 thousand, that's the cheapest. He [the "barracão" operator) buys that cheapest flour, at 5 thousand, 2 or 3 or 4 sacks, whatever he can, whatever the "barracão" uses. But he's going to sell at market prices, isn't he? If good flour is being sold in the market at 10 thousand, he sells at 10 thousand". ${ }^{46}$

But it is not only the "barracão" operator's purchases of goods from shops which are regulated by market prices. His dealings with local people who supply him with products such as cassava flour are also governed by such prices:

\footnotetext{
44 The contractor, however, is going to change the town sales outlet into a kind of "barracão". His workers buy on credit, and the cost is deducted from their wages at the end of the week.

45 A., resident already quoted.

46 J.A., already quoted.
} 
"They [the "barracão" operator] buy top quality flour [at the cheapest shop prices] and sell at commercial prices, the market prices being charged during the course of the week. It's like this: if it costs 10 thousand on the market, they increase that price of 10 thousand". ${ }^{47}$

This, however, does not prevent rural laborers and smallholders from continuing to look on "the shops" in general as an alternative to the "barracão":

"Buying at the "barracão"? I'm scared of the "barracão", you understand? It's not even worse for my family because God is good. Thanks to God and to men who are prepared to bargain. Because there in Palmares there is someone who has a stall ... he's not my boss, he's my father (...). ${ }^{48}$

\section{Conclusion}

About ten years ago a local historian in Pernambuco could say, without fear of contradiction, with regard to the towns and villages in the wettest part of the Agreste region:

"These villages, being the nearest settlements to the (swamps) outback, hold large "feiras", because the lower concentration of large estates allows a wider division of wealth: there are fewer rich or poor people and more people of average means. For this reason, "feiras" such as those at Camocim de São Felix, Cupira, Cachoeirinha and Capoeiras, despite their small populations, are much more important than those in the large towns of the Zona da Mata region, such as Goiana, Nazaré or Palmares". 49

A study of the markets in the Zona da Mata region suggests that this is no longer the case and that the "feiras" and the market are present even in the transactions that represent their negation, like the commercial practices of the "barracão" operator. The growth of the "feiras" in the sugar producing zone seems to cast a broader transformation, reversing the relationship between the "feiras" of the Agreste and the Zona da Mata.

\footnotetext{
47 Idem.

48 T.D., already quoted.

Correa de Andrade 1964: 159.
} 
"Of the "feiras" round here, Palmares is the best. The "feiras" in the Agreste are small.". ${ }^{50}$ "It's not only in Palmares, there's been growth in all these little places, like Batateira". ${ }^{51}$

The producers of Cupira, São Felix, Cachoeirinha, are bringing their produce to the Zona da Mata and many of those marketplaces are taking the leftovers from Palmares or are being transformed into "women's feiras". ${ }^{22}$

This growth in the "feiras" has not been continuous. Market traders and customers often refer to a recent past in which "things were better", "when the worker had money to spend in his pocket", or to a golden age when "produce was thrown out because there was so much of it". Not even the growth of the "feiras" seems to represent any increase in the purchasing power of the rural workers and smallholders. On the contrary, such growth seems to mirror closely the twists and turns in the history of the region.

Translated from the Portuguese by Jonathan Roberts.

Translator's notes by Fernando Rabossi

\section{Bibliography}

CIA. TELEFÔNICA DE PALMARES. 1965. "Palmares: dados históricos, geográficos e econômicos.” Lista Telefônica Oficial. Palmares.

CORREA DE ANDRADE, Manuel. 1964. A Terra e o Homem no Nordeste. São Paulo: Brasiliense. (2nd ed.).

GENESTOUX, Patrick Calema du. 1967. Le Nord-est du Sucre. Thèse de troisième cycle présentée à la Faculté de Droit et Sciences Economiques de Paris, Paris.

GONÇALVES, Fernando Antonio. 1966. Condições de Vida do Trabalhador Rural da Zona da Mata de Pernambuco - 1964. Recife: Instituto Joaquim Nabuco. IBGE. 1955. Estado de Pernambuco: Censos Econômicos - 1950. (Serie Regional, Vol. XVII, Tomo 2). IBGE: Rio de Janeiro.

50 Group of producer traders from the Agreste selling flour.

51 S., already quoted.

52 Some traders from the outback say that they only sell in the Palmares "feira", leaving the job of selling in their local markets to the women. 
IBGE. 1969. Censo Agrícola 1960: Pernambuco. (Vol. 2, pt. 2). IBGE: Rio de Janeiro. LEITE LOPES, José Sergio. 2013. "Entrevista com Moacir Palmeira." Horizontes Antropológicos, 19(39): 435-457.

MACIEL, Telmo Frederico do Rego. 1964. Nivel de Vida do Trabalhador Rural da Zona da Mata - 1961. Recife: Instituto Joaquim Nabuco.

PALMEIRA, Moacir. 1979. "The Aftermath of Peasent Mobilization: Rural Conflicts in the Brazilian Northeast since 1964." In: N. Aguiar (ed.) The Structure of Brazilian Development. New Brunswick, New Jersey: Transaction Books.

USINA CATENDE S.A. 1941. O Homem e a Terra na Usina Catende. Recife. 


\section{Photographic Appendix - Palmares, 1971}

Photos by Moacir Palmeira 


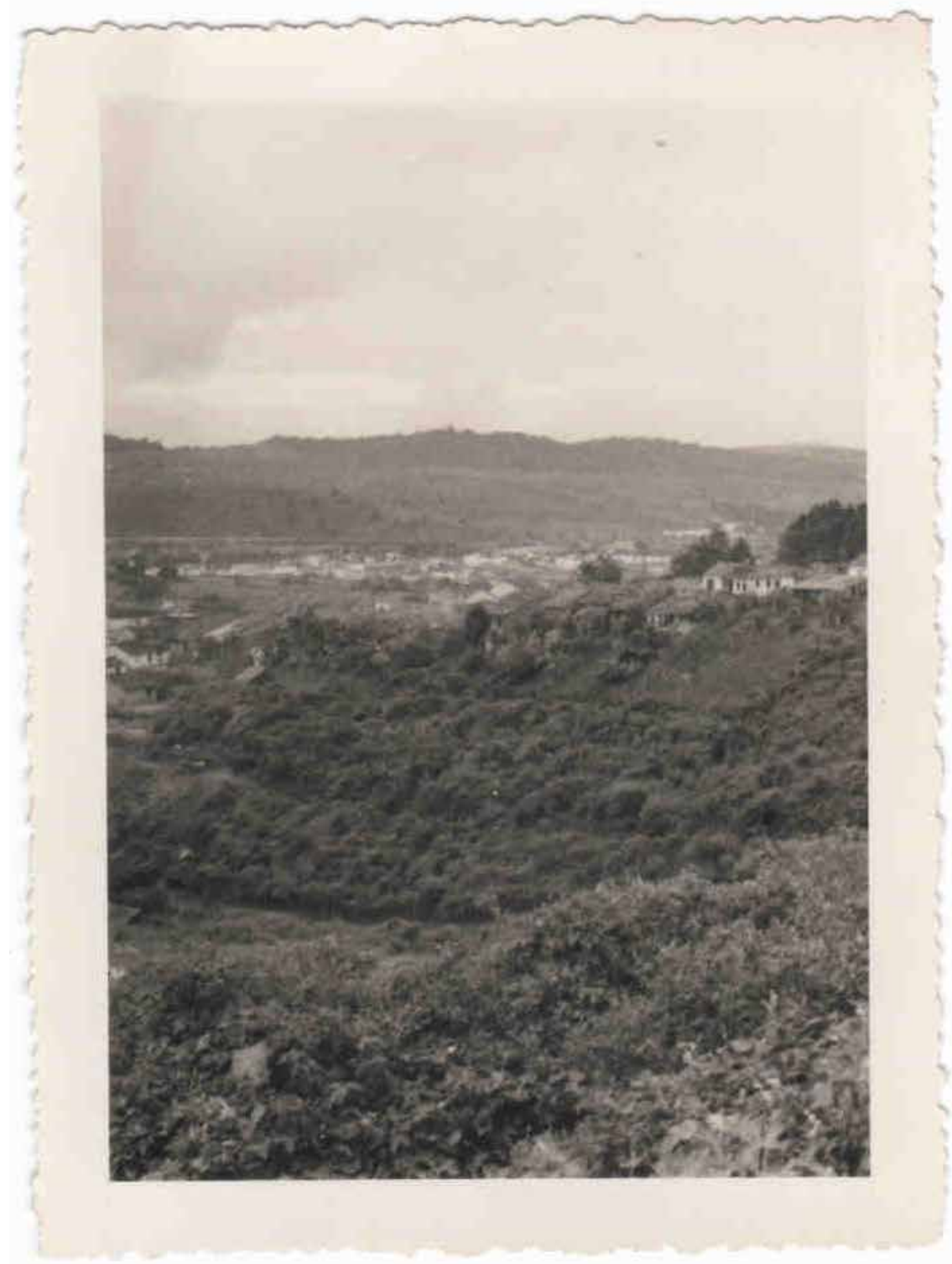




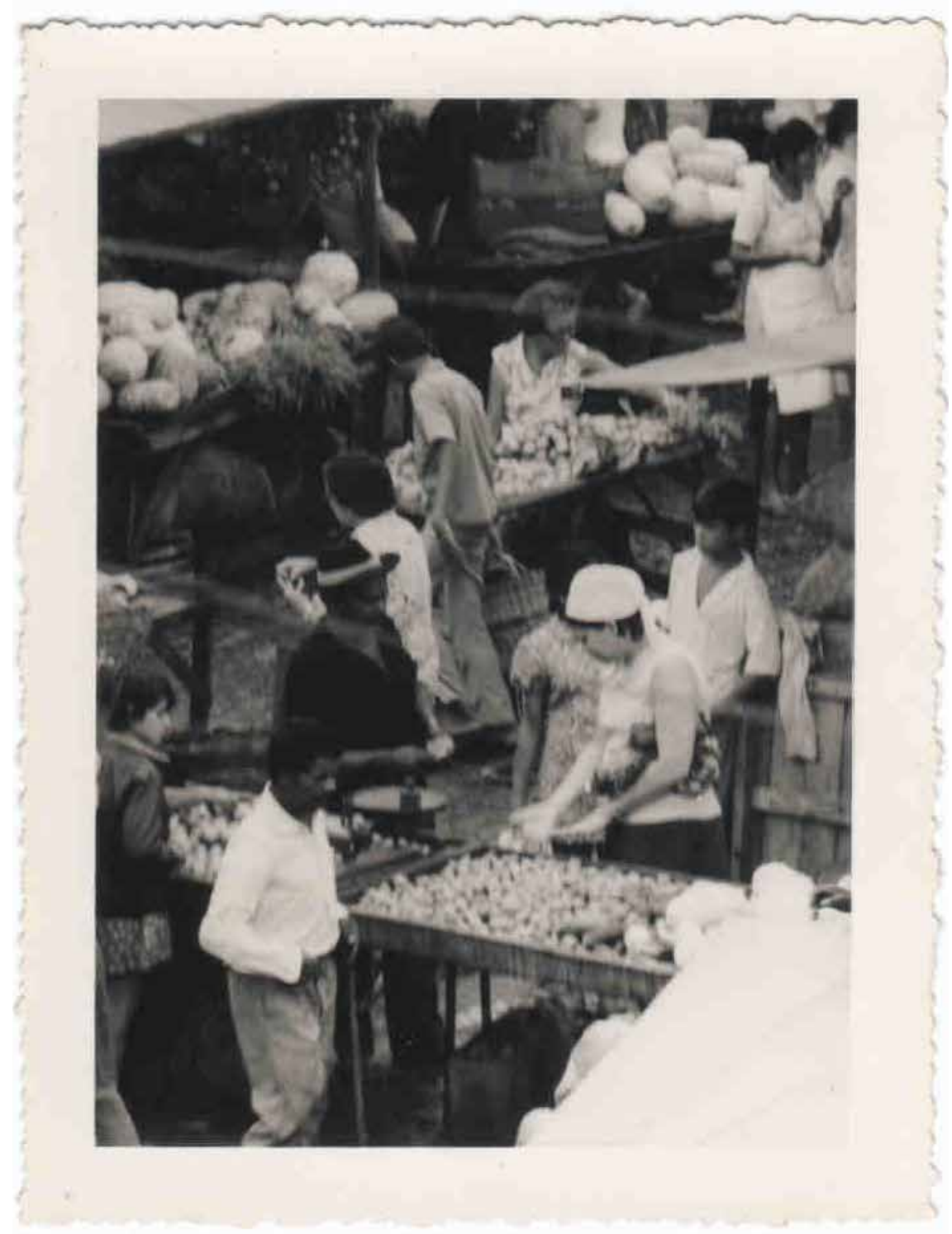




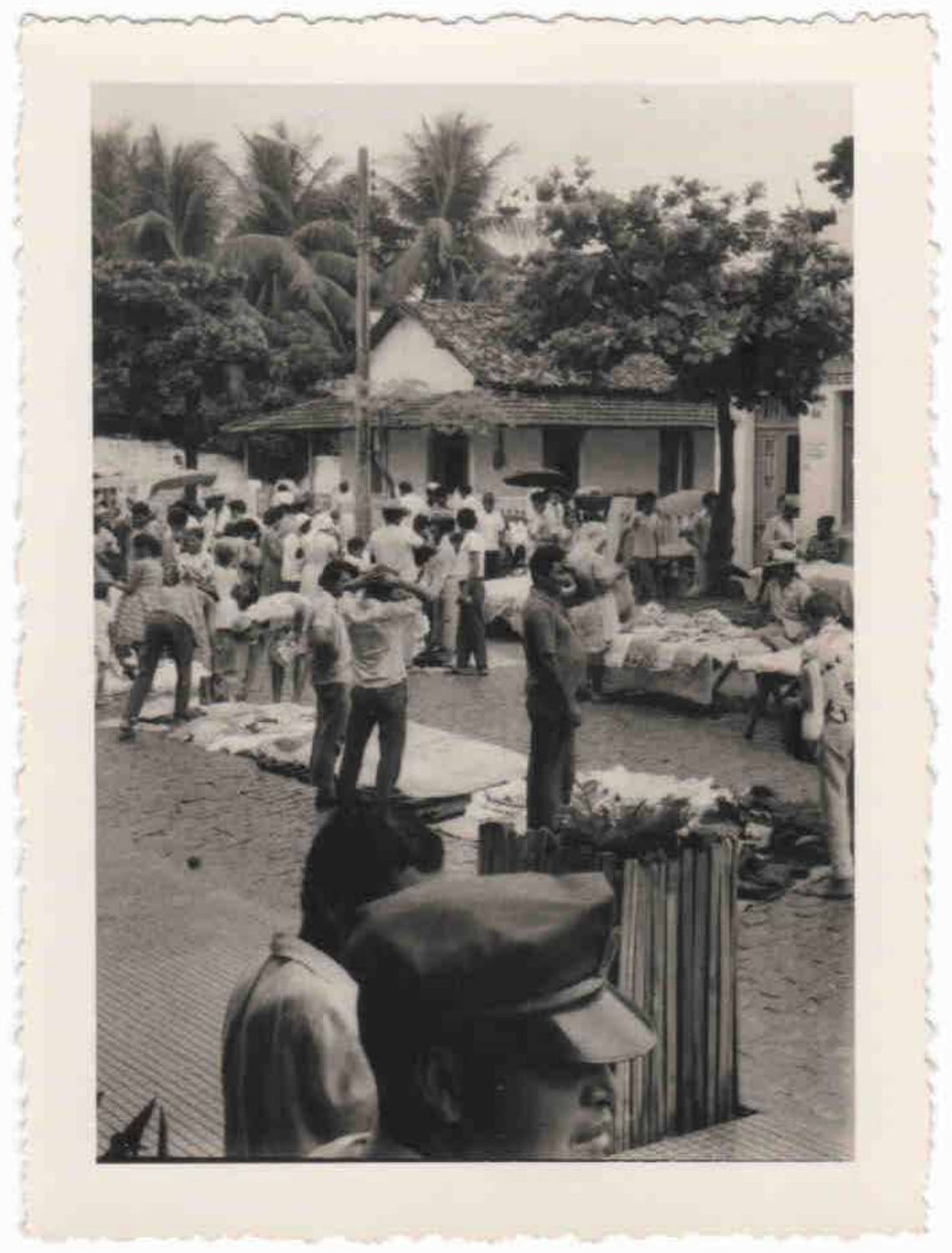




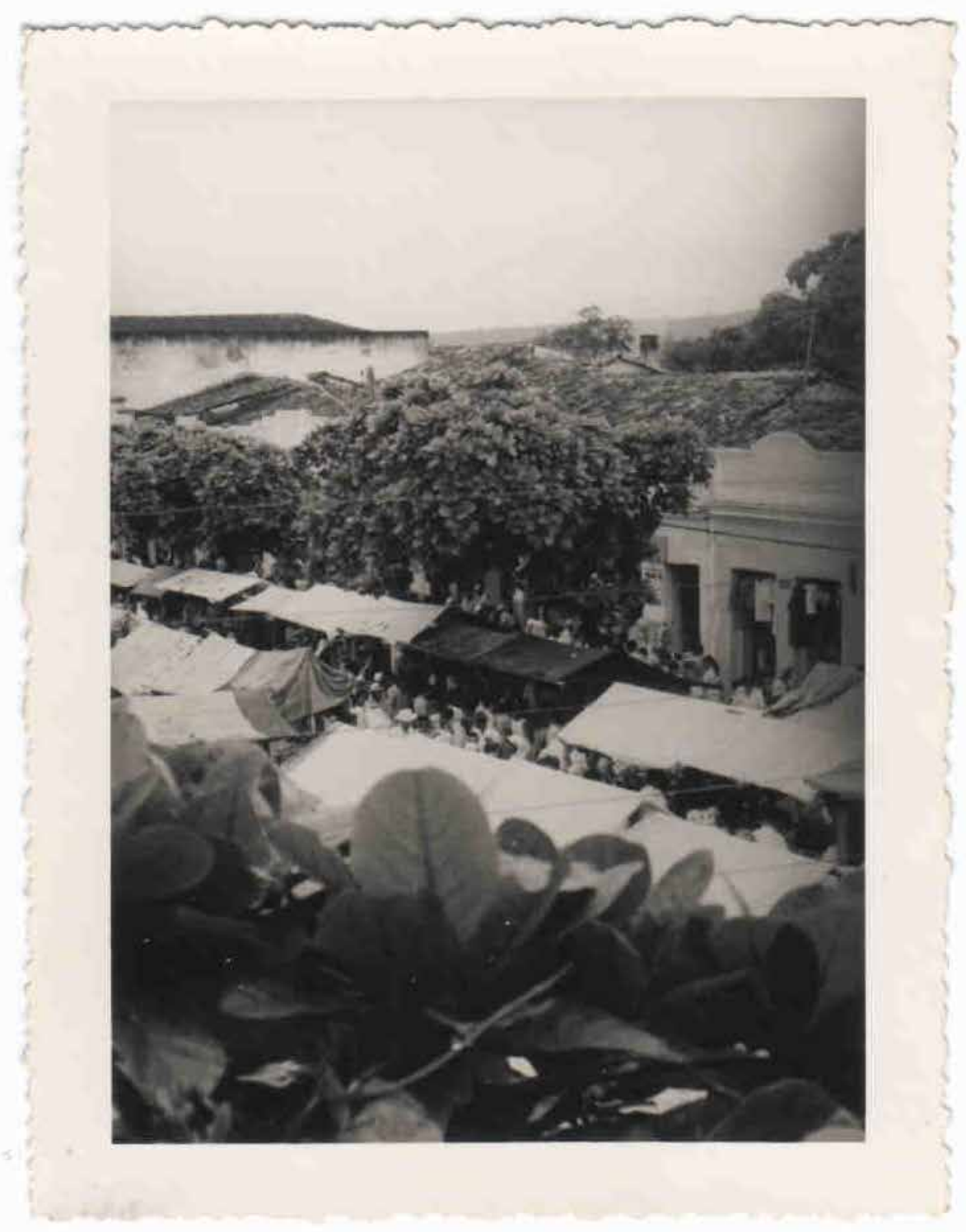




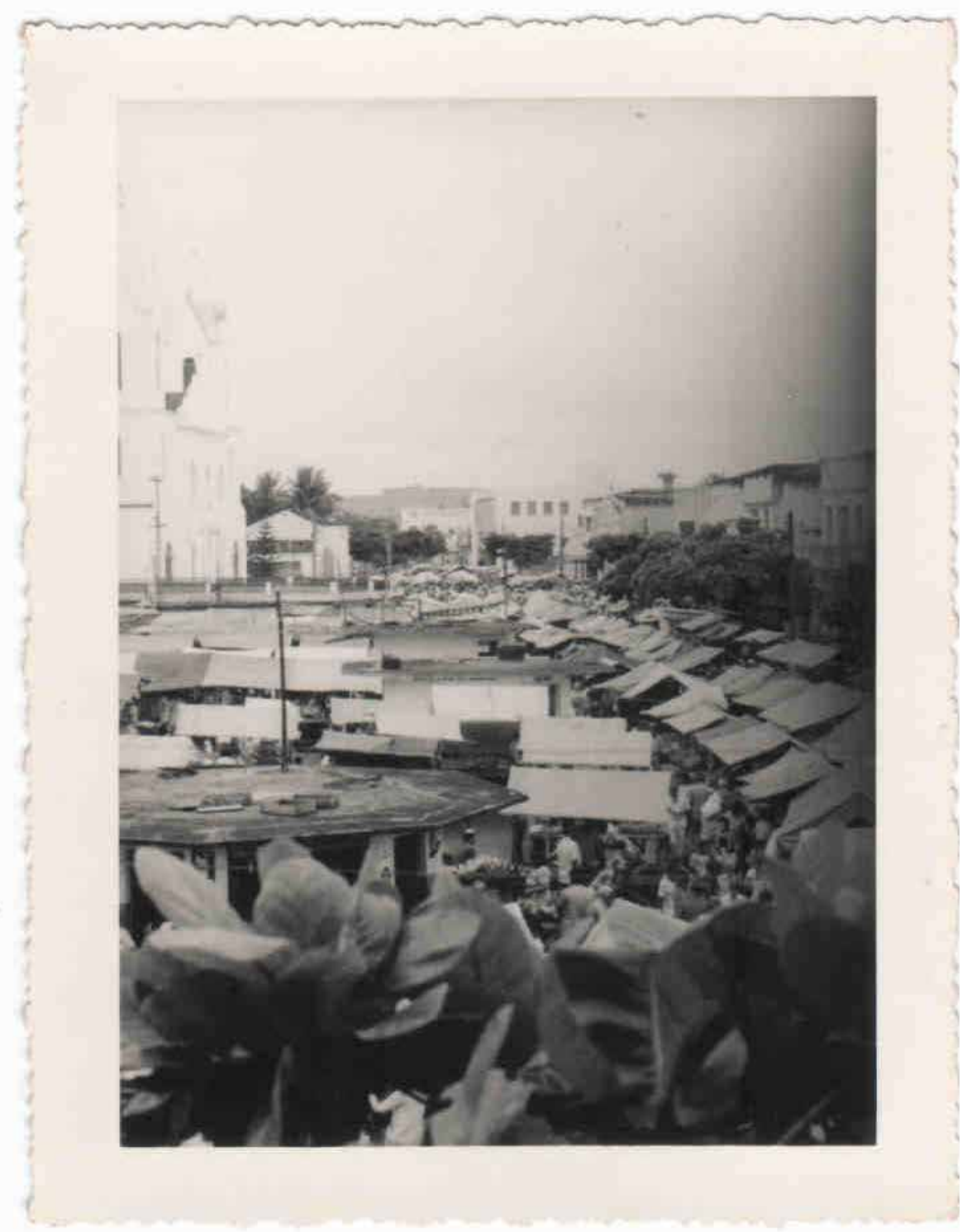




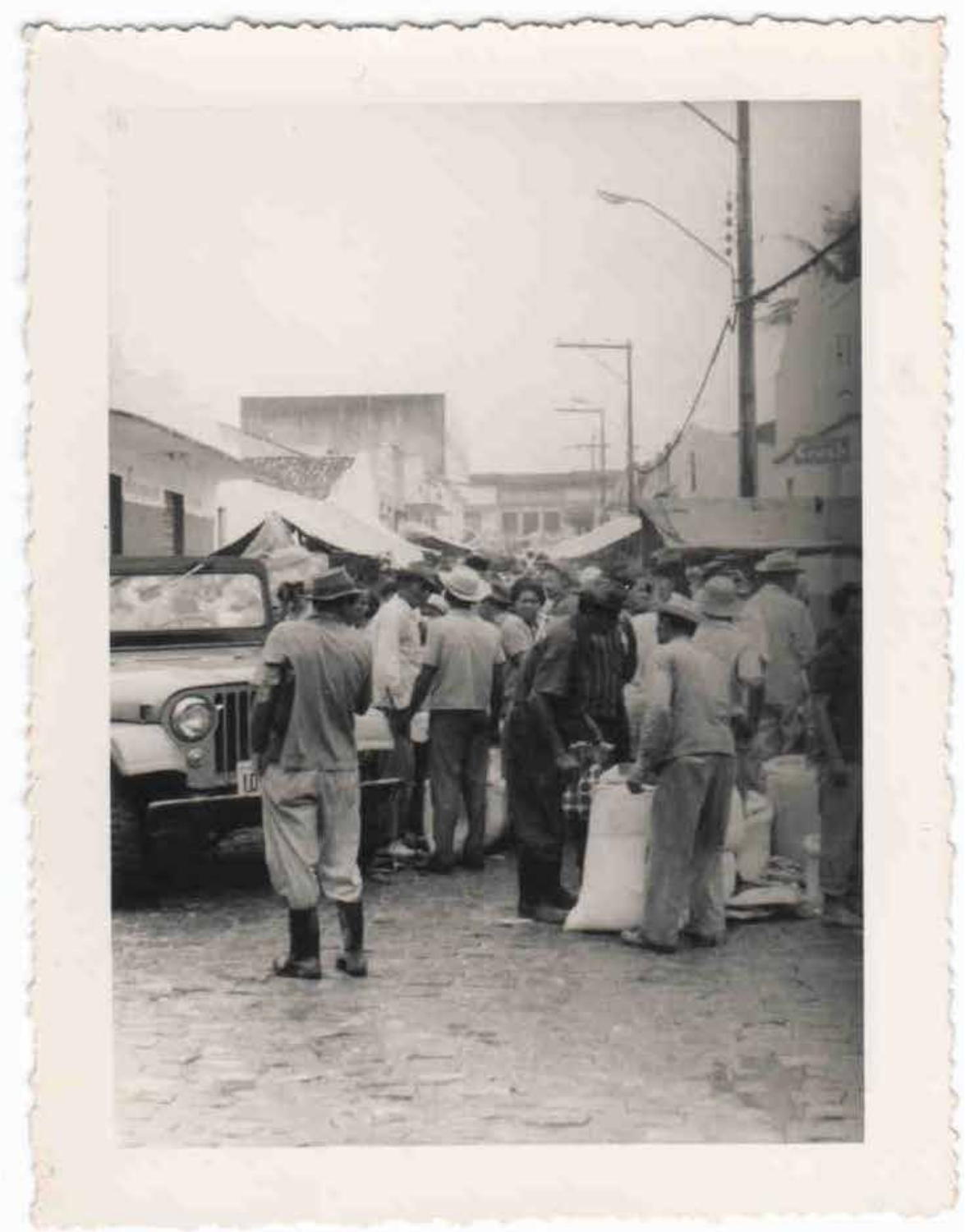




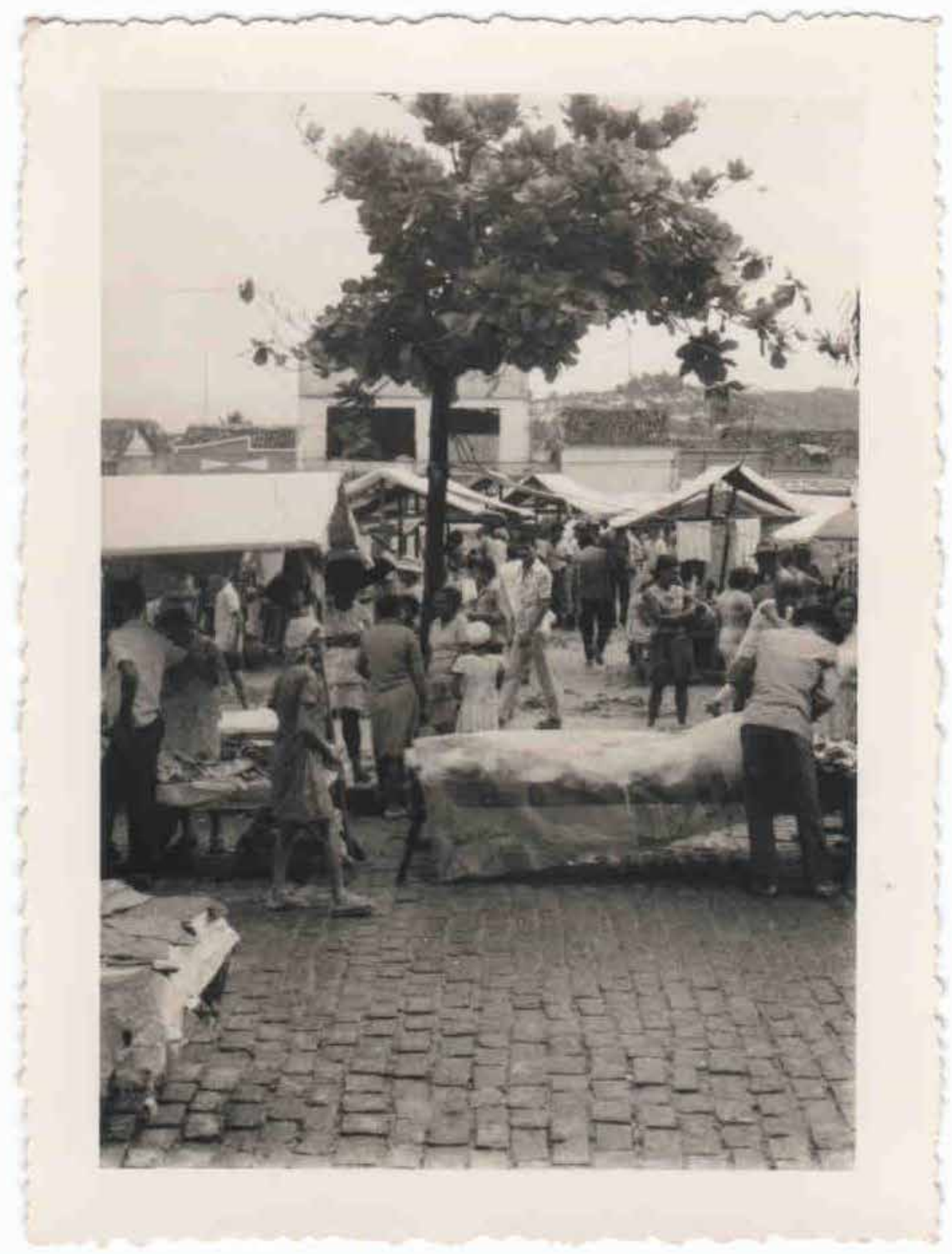




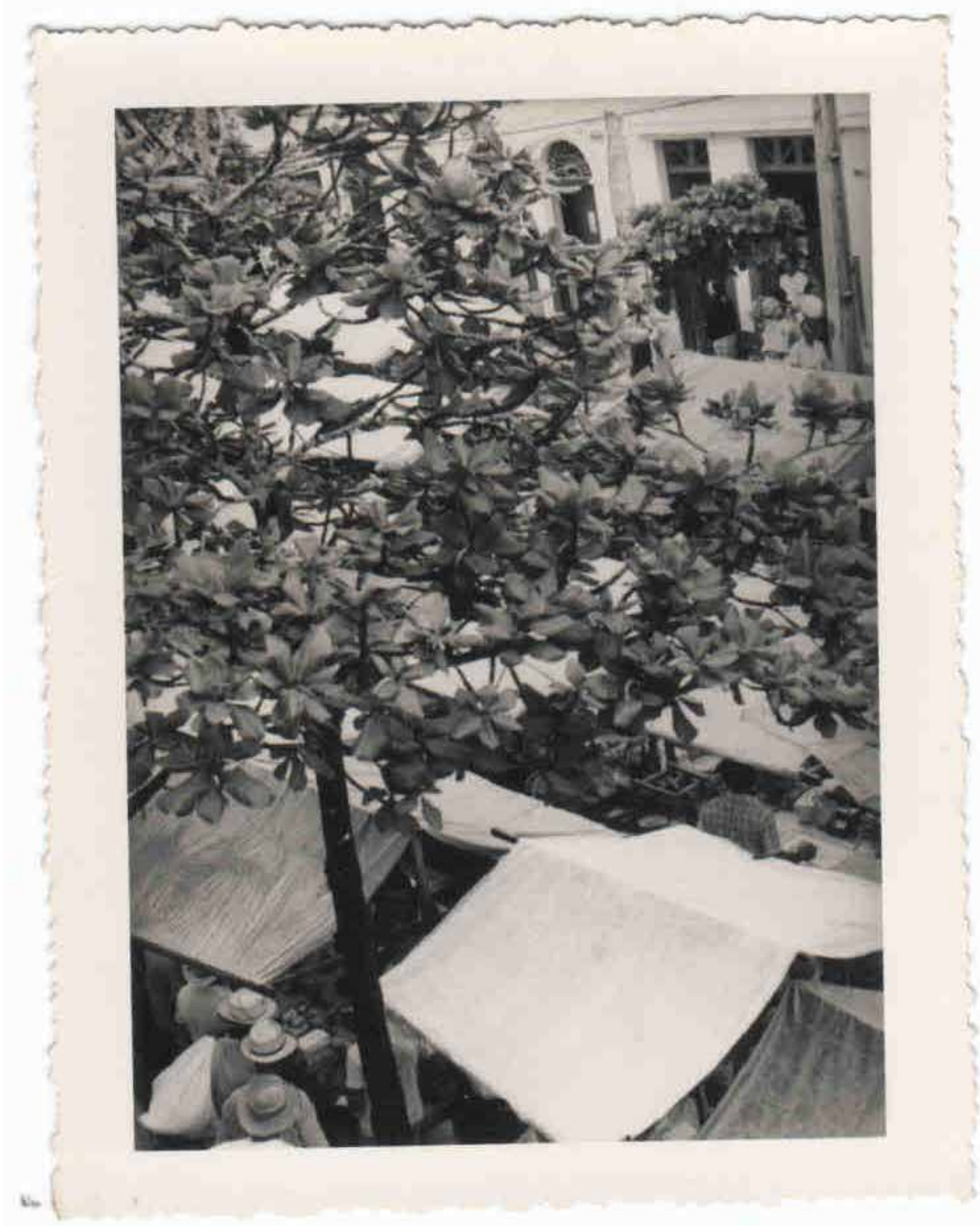




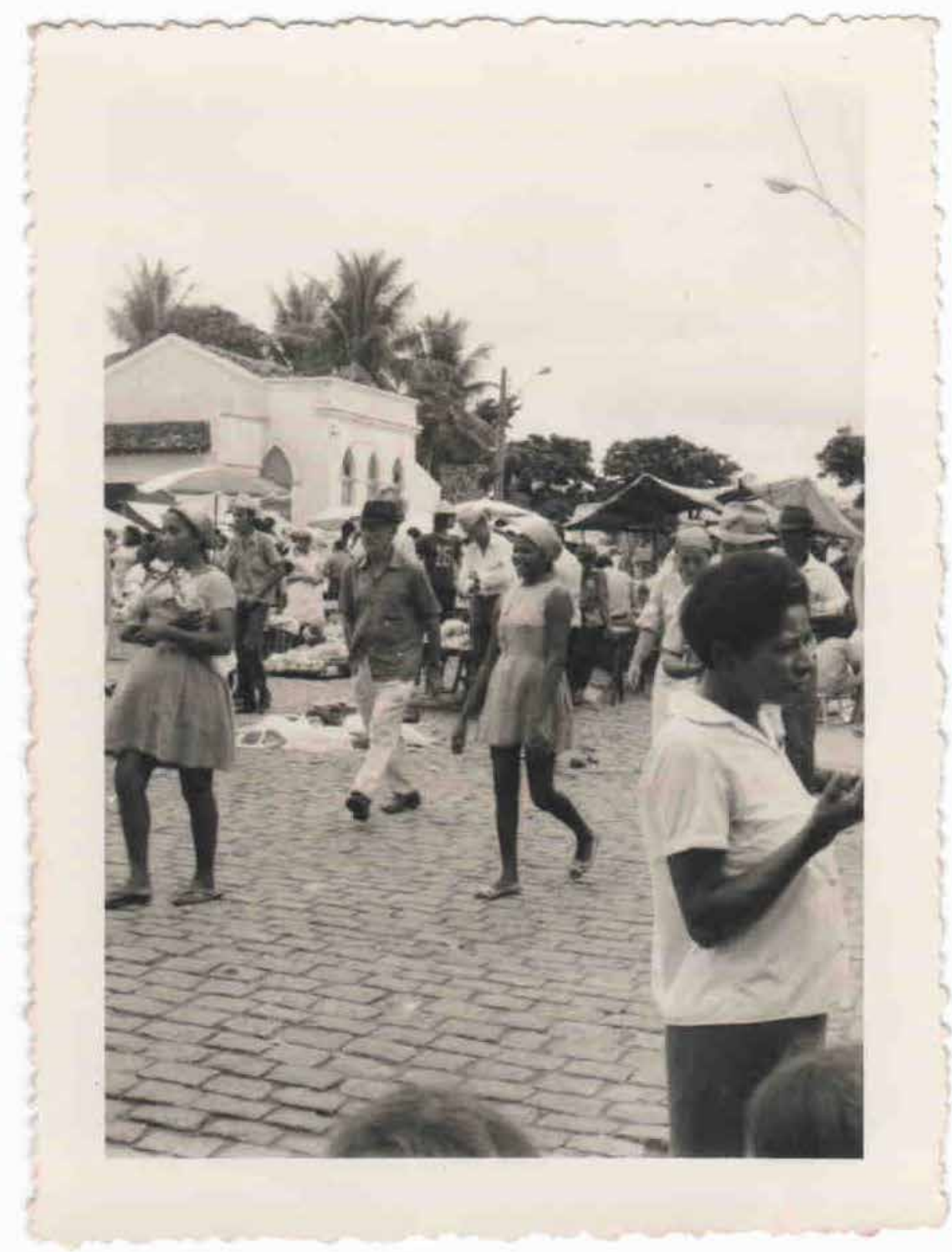




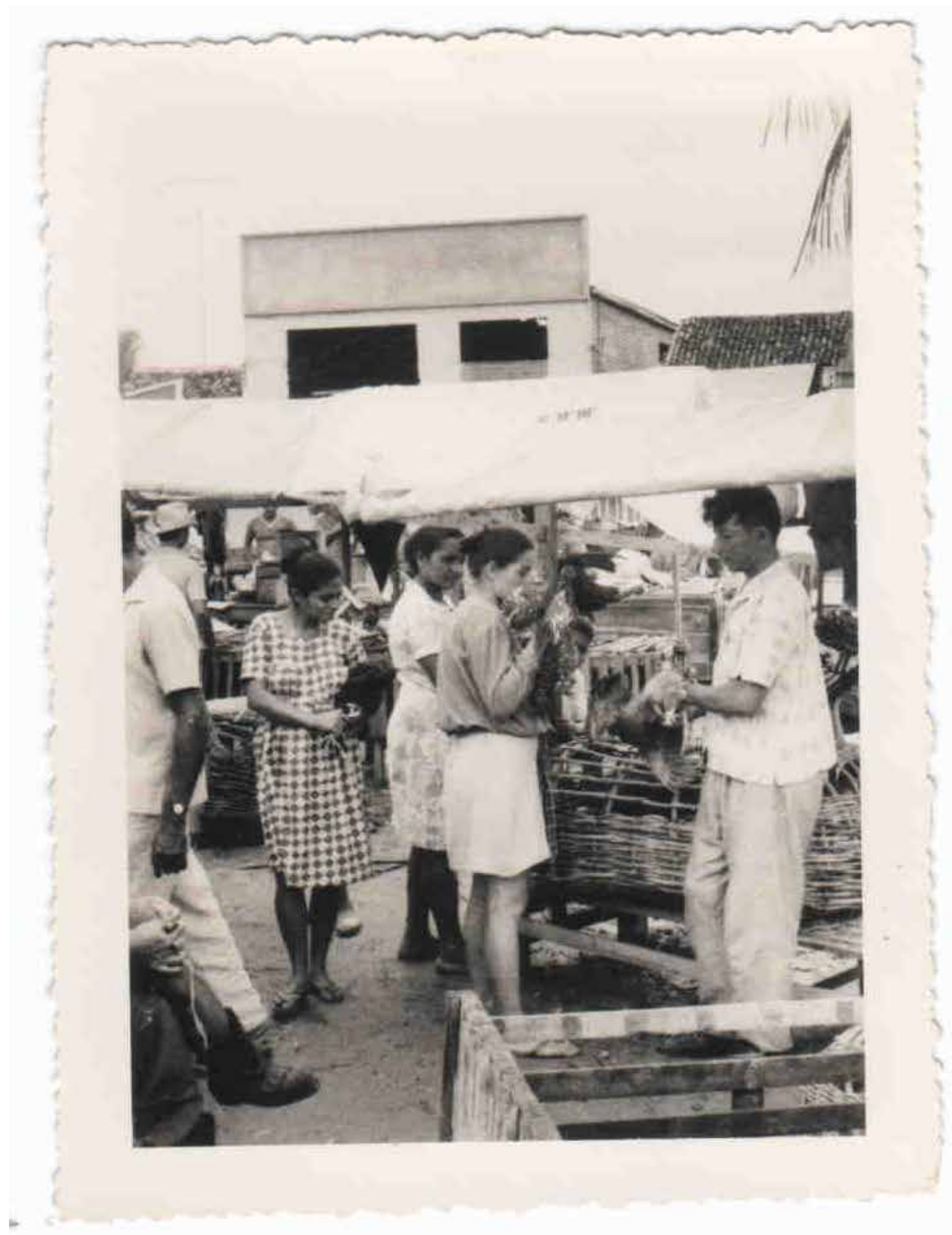




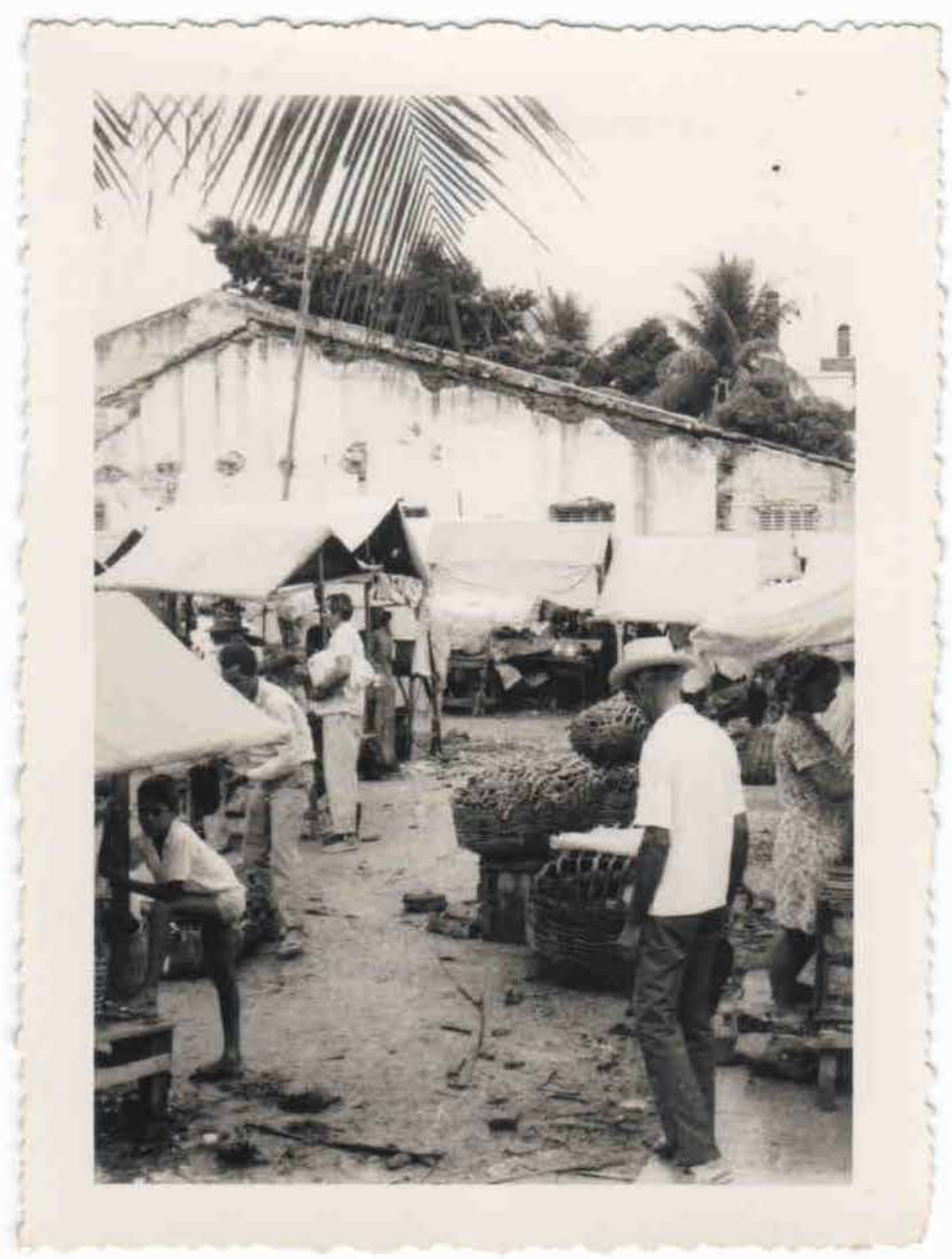




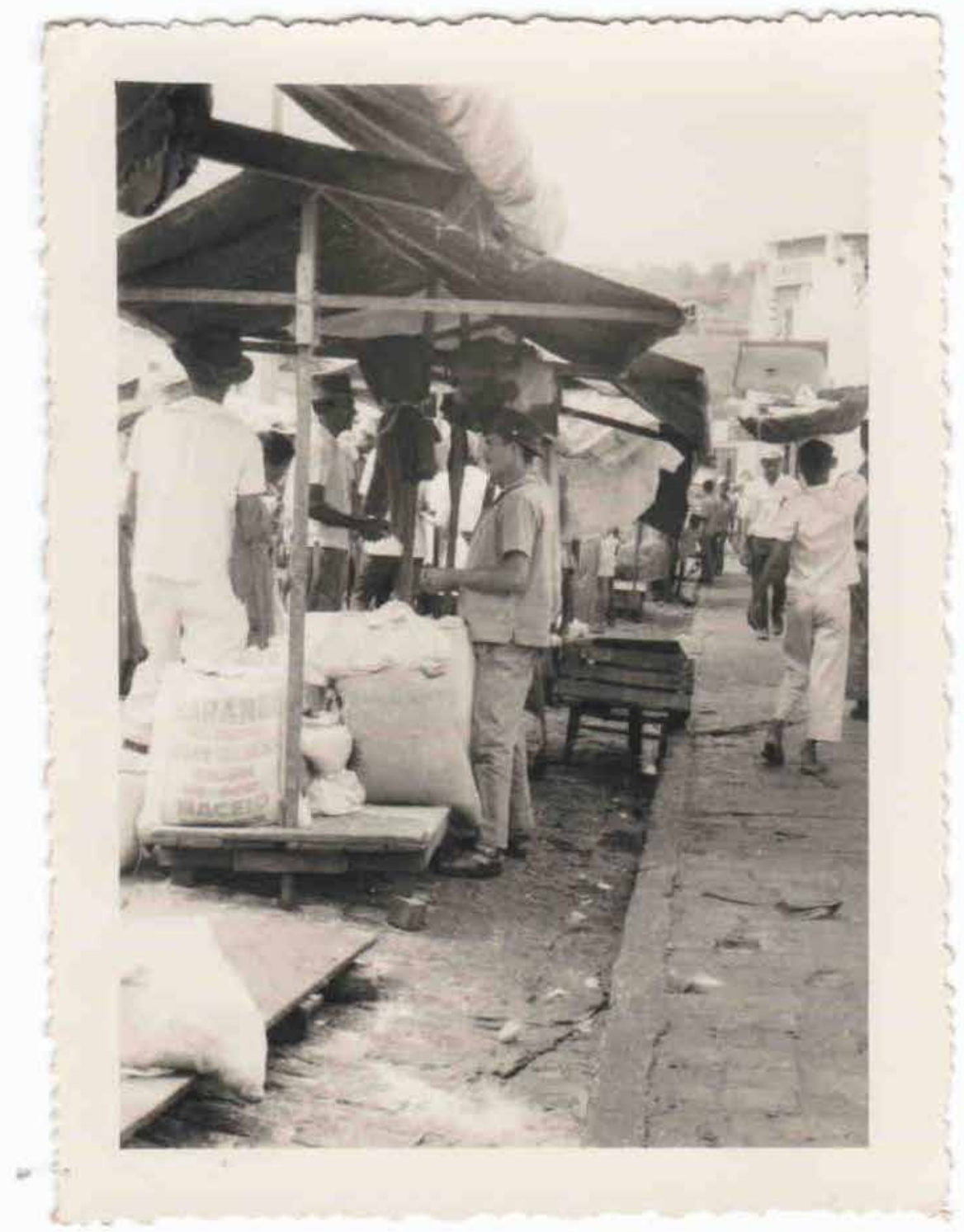

